\title{
Strengthening Digital Citizenship Through Digital-Based Civics Learning
}

\author{
Ernawati Simatupang ${ }^{1, *}$, Abdul Azis Wahab ${ }^{2}$ \\ ${ }^{1,2}$ Universitas Pendidikan Indonesia, Bandung, Indonesia \\ *Corresponding author.Email: ernasimatupang@gmail.com
}

\begin{abstract}
The development of the world of technology has had a major influence and impact on human life, especially in the world of education and the main users are high school students, where the function of technology is not only seen as a tool but also as a support for successful teaching and learning. Therefore, Civics as a subject has a vision in creating quality citizens. Advances in technology have been able to renew the learning environment to be digital-based so that it will have an impact on the formation and practice of citizenship. So that in this case the Civics teacher is tasked with creating learning strategies that can give birth to nuances of creativity in the competence of students as digital citizens. This study specifically examines how the implementation of teaching strategies and their impact on student character in the implementation of digital-based Civics learning in high school. This study uses literature studies with references related to the research theme. The results of the study show that strengthening digital citizenship through Civics Learning in digital-based high schools can be done by: 1) Civics teachers in SMA implementing digital-based learning strategies and models, 2) Civics learning in digital-based high schools can develop citizen competence creatively, 3) Civics learning in digital-based high school can make media to strengthen digital citizenship. The conclusion in this study is that Civics Learning in digital-based high schools has achieved the goal of increasing student creativity and participation in developing their potential.
\end{abstract}

Keywords: Digital-Based Civics Learning, Civics Learning, Digital Citizenship.

\section{INTRODUCTION}

The development and progress of science and technology have now become a civilization that influences the education process in Indonesia. So that this impact will change the way of education to achieve its national education goals. Technological progress in education is marked by the development of information and the use of learning media as a means of supporting the achievement of learning and educational goals.

Citizenship education which have an important element in responding to the challenges and statements above needs reforms in the implementation of education and the learning process. This statement is in line with the nature and purpose of civic education itself to form smart and active citizens who are responsible for their rights and obligations (Wahab \& Sapriya, 2011).

As the executor of the vision and mission of education that creates national character, Civics in its implementation need to be consistent in creating a national moral character, has a noble character, and can realize the goals of the Indonesian nation, therefore to make this hope come true, Civics need to be carried out in a directed and planned manner so that they are fulfilled. an educational process that creates active, participatory, and responsible students by the times, but must not forget its character as a moral Indonesian nation

Talking about the character and progress of a nation, the main actor as a determinant of the character of the nation in this discussion is the young generation, in this study the young generation will be focused on adolescents or high school children. The advances in technology and information that enjoy and benefit the most in various meanings are the Indonesian youth or teenagers.

So based on the data and facts obtained by the researchers. Then to strengthen the data above, the researchers also added the results of research by KOMINFO and UNICEF in 2014 concerning the behavior of adolescents in using the internet. This research is a UNICEF program on digital citizenship and safety which aims to find out and follow up on the impact of using ICT on the way of life of children and young people in developing countries, this study also directs how safe the use of digital media by Indonesian children and adolescents. The survey results found the following facts:

\begin{tabular}{|l|l|l|}
\hline NO & \multicolumn{1}{|c|}{ Findings } & \multicolumn{1}{c|}{ Description } \\
\hline 1. & $\begin{array}{l}\text { There are 30 million } \\
\text { Indonesian children } \\
\text { and adolescents who } \\
\text { use the internet and } \\
\text { digital media. }\end{array}$ & $\begin{array}{l}80 \% \text { of the data are } \\
\text { internet users, and there } \\
\text { is strong evidence of a } \\
\text { digital divide between } \\
\text { them. }\end{array}$ \\
\hline 2. & $\begin{array}{l}\text { This study is the first } \\
\text { study with unique } \\
\text { data on groups of }\end{array}$ & $\begin{array}{l}\text { In this study, there is a } \\
\text { very noticeable gap in } \\
\text { urban children and }\end{array}$ \\
\hline
\end{tabular}




\begin{tabular}{|c|c|c|}
\hline & $\begin{array}{l}\text { children and } \\
\text { adolescents who } \\
\text { have never used the } \\
\text { internet }\end{array}$ & $\begin{array}{l}\text { adolescents of } 13 \% \text { who } \\
\text { do not use the internet, } \\
\text { and } 87 \% \text { constitute the } \\
\text { rest. }\end{array}$ \\
\hline 3. & $\begin{array}{l}\text { This study reveals } \\
\text { that the majority of } \\
\text { them are online } \\
\text { media users for more } \\
\text { than one year }\end{array}$ & $\begin{array}{l}\text { The study reveals that } \\
69 \text { percent of } \\
\text { respondents use a } \\
\text { computer to access the } \\
\text { internet, } 52 \% \text { use a } \\
\text { cellphone and } 21 \% \text { use } \\
\text { a smartphone }\end{array}$ \\
\hline
\end{tabular}

Tabel 1 Riset Kominfo dan Unicef Sumber : Processed by Researchers

Therefore, based on the research of the survey institute above, it can be concluded that the use of social and digital media is inseparable from the daily life of Indonesian adolescents, and the impact of using digitalbased media will change the patterns and structures of adolescent social life. Digital degradation and division will have an impact on the character building of Indonesian youth. So that the results of the research above are evidence of a decrease in the policy of using the internet by a generation that is included in the generation of digital citizenship.

Then, based on KOMINFO's research in 2020 and 2018 on the use of the Internet and technology in education. In the survey, an analysis of the use of technology in education was carried out on 4,014 SMA in 34 provinces. in 2018 which resulted in 16, 23\% use of radio in learning, $25.59 \%$ using television, $73.56 \%$ using telephones, then the proportion of teachers who have qualifications in the technology sector is $10.10 \%$ Kementerian Komunikasi dan Informatika (kominfo.go.id).

Therefore, as the main actors in responding to these challenges, Civics teachers must be able to have the ability to realize the competence of citizens globally by reflecting on their duties as teachers by providing global knowledge to create knowledge and competencies of citizens with modern or global characteristics. but does not violate the values and norms according to Pancasila and the 1945 Constitution.

To accompany the development of technology which also propagates in the function of media and learning resources, teachers and parents must be able to become the first elements to prevent negative impacts from the use of technology media and the internet. Teachers must be able to compose independent creativity that can give birth to the use of technology media as a good learning resource, and not used as a tool for deviating national character that is not by Pancasila values.
Therefore, Civics have an important role as a means of controlling the use of technology and internet media by high school students, as well as being able to motivate children to use their learning resources for their means of communication and learning information media. So, in this case, the role of the teacher is to create a digital-based learning strategy as a guide for educational renewal, and hopefully the creation of digital citizenship that is in accordance with the character of the nation and the values of Pancasila.

Technological advances also signify the birth of digital citizenship, namely the use of digital media based on digital ethics. Therefore, this is a new challenge that requires harmonious cooperation between teachers, parents, and the government to create productive citizens in technology but not forgetting and leaving their true identity as an ethical and cultured nation in accordance with the breath and values of Pancasila.

So that the formulation of the problem in this study is to try to analyze how the teacher's efforts to create digital-based learning strategies to strengthen the character of digital citizenship.

And the purpose of this research is to study and analyze how the use of technology by high school teachers as a medium and learning resource as a means of strengthening the character of digital citizenship of students (digital citizenship).

\section{METHOD}

This study uses a qualitative approach with a literature study method. The qualitative approach to this research is the type of data collection using secondary data, namely data that provides indirect data to the researcher. (Sugiyono, 2006).

While the literature study method is a method deemed appropriate by researchers to support the research results of researchers. Literature study is the process of finding information and research data sources by reviewing and analyzing various data sources including articles, books, journals related to research interests, which will then be developed, generalized, and conclusions are drawn. (Nazir, 2014)

\section{RESULTS AND DISCUSSION}

\section{A. Digital Citizenship}

Based on the results of studies and analysis by researchers, the results of research on strengthening digital citizenship through digital-based citizenship education for high school students are obtained.

The results of the first research are that the concept of digital citizenship can be strengthened through civic education in schools, which is carried out by teachers with planned and systematic efforts that are equipped with learning models and methods as a form of strategy to develop the character of digital citizenship. 
Digital citizenship is a concept of citizens who live in the environment and community in the digital era (Feriyansyah, 2015). Then this research is based on new thoughts and concepts pioneered by Mike Ribble (2014) in his book on Digital Citizenship in School. That to answer the challenges of the digital era of educators, it is necessary to have a strategy to develop the competence of citizens globally, as well as train the independence and participation of citizens of a world nature. Then in his book, it is also explained that Civics are one of the subjects that are responsible for the practice of student citizenship that is carried out in the digital era.

Based on this theory, teachers need to develop digitalbased learning strategies to introduce students to their role as digital citizenship and be able to form a personality that is responsible for creating a digital atmosphere with nuances of character according to Pancasila and the 1945 Constitution.

Then, if the plot is examined, digital citizenship will not be separated from the subject of the study, namely the younger generation. In the theory of Howe and Strauss's generation, which grouped several generations with certain characteristics, including generation Y (19811994). According to this theory, this generation is a generation that has curiosity, and its interactions use technology such as cellphones, computers, and the internet. While generation Z (1995-2010) is a net generation that is multitasking, which is capable of doing various kinds of tasks at the same time (Howe \& Strauss, 2017).

Furthermore, according to the theory of Ribble and Bailey (2014) that in the practice of citizenship, there is a new type of citizen, namely the type of citizen with a new life pattern, which has characteristics and characteristics whose daily activities are related to technology.

Then to strengthen this theory, in his writing (Suryadi, 2009) says that the characteristics of digital citizenship are marked by the habitual patterns of behavior and activities of an individual who is accustomed to digital media. Then Ribble and Bayle (2014), formulate there are 9 elements of digital citizenship, which can be described as follows:

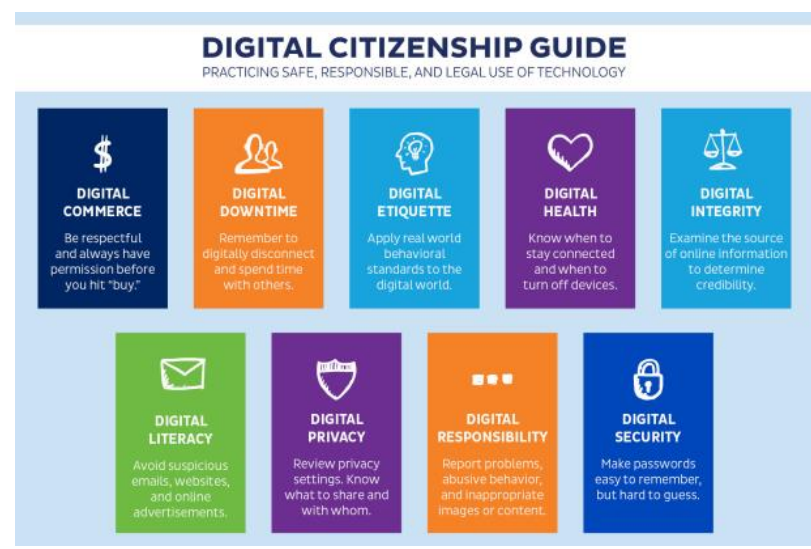

Figure 1 Nine Elements Of Digital Citizenship Ribble and Bailey (2014)

\section{Source : 9 Lessons To Teach Children About Digital} Citizenship (safesitter.org)

So based on the picture above, this theory becomes a guideline for citizens in using digital media. This guideline will provide benefits to citizens to train ethically in the use of digital media so that there is no misappropriation, deviation, and conformity with applicable norms.

The characteristics of digital citizens according to Ribble's theory consist of digital access, digital commerce, digital communication, digital literacy, digital etiquette, digital law, digital rights and responsibilities, digital security. These citizen characteristics examine citizen participation, citizen transactions in business and the economy, exchange and interaction of information, the ability to interact and digital use purposes, ethics and rules in digital use to the way citizens are held accountable for their digital behavior. (Prima Roza, 2020)

Then, other findings were found by researchers that the characteristics of digital citizens can be strengthened through citizenship education, namely, students can shape their digital ethics, can practice their learning independence, and participate actively in public and global issues related to themselves.

So this statement is consistent with previous research conducted by Prima Roza on Digital Citizenship: Preparing Millennial Generation For Democratic Citizens In The Digital. The research discusses the role of generation as digital native and digital citizenship in facing the challenges of the digital era, Prima Roza said that digital citizens are related to how they analyze ethical choices, which can be written, communicated and the impact their use of digital media has on others and their environment.

Then to strengthen this research, researchers also analyzed research conducted by Blummer \& Kate about digital media users who are motivated by the existence of new media as the active actors are the younger generation and have clear goals, namely to fulfill expectations, content, needs, and motivation for their use of social media. Then at the same time, there is research on the influence of social media in the digital era on the form of political participation and social engagement of citizens through social media, this involvement will shape active participation and communication skills by citizens. (Reichert, R., \& Karin, W.K., 2018)

Whereas the difference with research researchers is that this study tries to examine how to strengthen digital citizenship by students through digital-based Civics learning, the object of study in this study is high school students who are then provided with knowledge through teacher strategies in strengthening digital ethics of high school students in using digital media, internet, etc. through digital-based Civics learning.

So that according to the analysis of researchers in their study digital citizenship contains a broad meaning, 
is a grouping of the existence of certain individuals or groups, who have the right to use the results of progress and civilization in the form of information technology, can participate actively and be based on applicable rules, and become a person who develops through his understanding of technology.

Through the above statement, the researcher formulates that the requirements for becoming digital citizenship are if he is mature and wise, has been able to master the benefits of technology, and can distinguish the functions and benefits of technology that are good for him.

As we know, the characteristic of digital citizenship is that it is accustomed to interacting with the environment using digital media, and as a measure for the development of morals and behavior by the younger generation. So that by the subject of this study are high school students who are included in the millennial generation who have a dependence on the use of digital media. The ability to operate digital media is expected to provide positive values for him.

It is hoped that the ability of high school students as the millennial generation can be used properly for the benefit of their learning, making their learning resources meaningful and varied. And the hope is that he will be able to grow into an adult citizen who understands technology but does not forget his ethics and character according to the values of Pancasila.

\section{B. Development of Digital-Based Civics Learning}

To realize the character of digital citizenship that is in accordance with the character of good and smart citizens, it is necessary to have a means or a forum that can realize these expectations. This hope is the common hope of all elements related to the goal of forming good, smart, and responsible citizens.

Therefore, Civics is one of the right steps to realize the above expectations, to prepare young citizens according to the characteristics of the character of digital citizenship Civics need to do the following:

First, to prepare citizens who have the characteristics of digital citizenship, Civics can develop using a digitalbased learning model, so that all forms of learning activities are directly related to learning objects, and the learning output will be more meaningful.

Furthermore, to strengthen implementation by these questions Zook (in Prima Roza, 2020) proposes that to realize an active participation of citizenship character, teacher education actors together with students need to first understand new concepts in learning about digital citizenship, the use of technology. Thus the expected learning competence can be achieved and carried out well.

Then in his writing (Zook, C., 2019) that there are main concepts that must be mastered by digital citizens, namely, the concept of empathy, digital functions and ways of working, computer literacy, and being able to apply and anticipate gaps that occur due to media use. digital.

Then to develop a digital citizenship model, researchers used a theory (Graeff, 2018) about the framework for digital citizenship, while the development of this framework consists of:

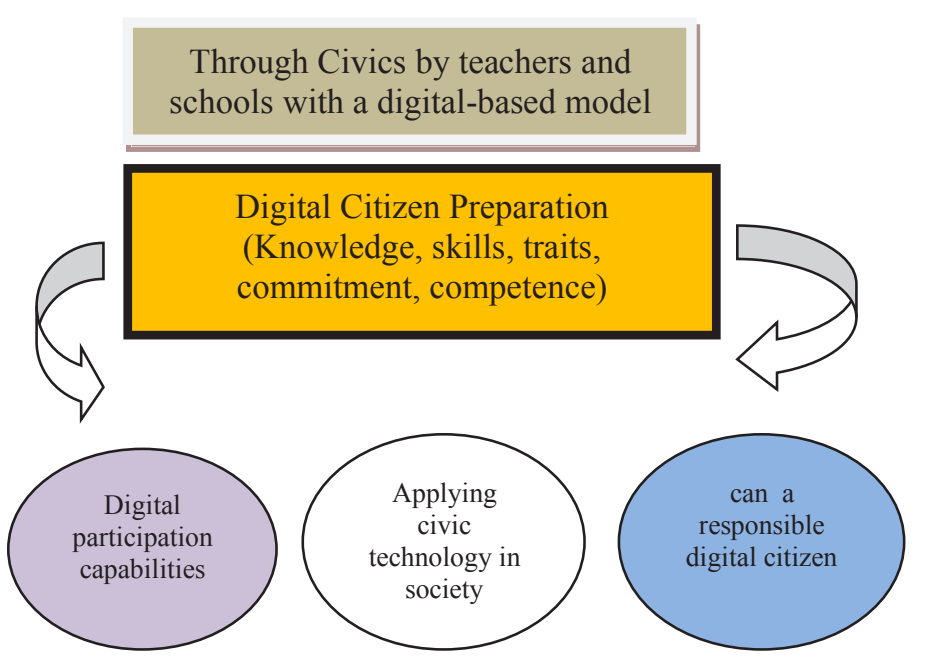

Figure 2 Digital Citizenship Framework

Source: Graeff, 2019

So that based on the formulation of the Graeff theory model above, it becomes a benchmark for teachers to develop learning models through digital-based learning that will be taught to high school students so that the expected competence of citizens can be realized.

Second, based on the results of the researcher's analysis that teachers can apply a digital-based Civics learning model using problem-based methods and materials, which can explore student knowledge. This is in line with the opinion (Munir, 2017) that digital learning orientation is material that can be accessed anytime and anywhere whose benefits are to train students' independent learning abilities, and digital material can also be sourced from digital media owned by students.

So that this statement becomes a benchmark for the implementation of digital learning, namely to provide a value for independence in student learning. In the same book, it is also added that students' digital learning strategies can access their learning resources in a large amount of time, and provide opportunities for students to play an active and interactive role in their learning. (Munir, 2017)

To achieve the competence and characteristics of digital citizens, high school teachers need to understand that digital learning design is an effort made by educators to achieve the principles of free, independent, and up-todate learning. (Munir, 2017) 
Therefore, based on the above statement, Civics are a bridge that has the most harmonious and appropriate relationship as a forum to strengthen the character of digital citizens of high school students. Teachers can apply digital-based Civics learning as a means of supporting the achievement of the goals of citizenship education and to strengthen the character and ethics of young citizens so that they can be said to be citizens who have rules and ethics in using their technological media.

In developing digital-based Civics learning materials to strengthen the character of digital citizens, according to researchers, the material must be global and interesting and updated issues according to the times. So this is by the research conducted by (Baehaqi \& Aulia, 2018) which states that the progress of ICT which is also felt by the world of education has led to teachers 'efforts to create Civics learning which provides value strengthening of citizens' global insight competencies to achieve the characteristics of digital citizenship

Then, the formation of this global insight is also explained in his book (Wahab \& Sapriya, 2011) which states that efforts to provide material with the theme of global insight will shape students' perspectives and are not limited to issues of their country, but also broaden to include world issues. Of course this is an implementation that has been included in learning tools such as syllabus, lesson plans and other evaluation materials.

Furthermore, Cogan (in Wahab \& Sapriya, 2011) added that the fulfillment of global insight by citizens is marked by the characteristics of citizens living in the $21 \mathrm{st}$ century. These characteristics include, the ability to see and approach global problems, cooperate and interact with others, understand and tolerate different cultures, the ability to analyze problems and solve them.

The competence described by Cogan can of course be achieved if it is applied through citizenship education, so this is by the objectives of Civics which create citizens who have knowledge, skills, and character who are intelligent and responsible for themselves and their nation.

Third, for the formation of digital citizens to be by the character of the nation, steps that can be taken include focusing on the civics curricular goals themselves. As has been explained in research (Feriyansyah, 2015) regarding the vision for the formation of digital citizen character, that the formation of digital citizen character must be able to describe the nuances of learning in the 21st century or digital era and information in which there is a center for developing curriculum vision such as learning Intelligence in social, cultural dimensions, political economy and technology.

Furthermore, to strengthen the character of digital citizenship, teacher students can act as a hidden curriculum, which is the aim to develop material that is by local and global facts, cases, and events that can support the implementation of the concept of digitalbased Civics learning to strengthen the character of digital citizens who have insight. global (Walangadi et al., 2020)
Furthermore, to strengthen the above statement, based on the results of the researcher's analysis that teaching global insight material on Civics through digital learning can be done using problem-based and digital learning models, for example, the teacher can provide projectbased learning collected through student digital media, so, in this case, requires students to look for problems through their learning resources, then train students' independence. Digital-based Civics learning will indirectly involve students directly to participate in analyzing facts and issues that are happening in the environment and the world. So to apply it, teachers need to understand learning concepts such as inquiry, discovery, and other problem-based models.

In addition, the learning approach that can be implemented by teachers to strengthen student digital citizenship can be done with an approach that develops students' global competence by using digital-based learning, starting from providing material to learning evaluation.

Then the teacher can apply a model that describes creative learning innovations, in which there is psychological learning and nuances of giving digital characters as a form of the role of Civics teachers in shaping citizens. This is in line with WW's opinion. Ays (in (Walangadi et al., 2020) who says that "the approach that teachers can use to students should use an approach that develops pedagogical competencies to develop students' global citizen abilities.

Then in the application of digital-based Civics learning, it can be applied using internet-based learning, or it can even be done with the application of learning using the Zoom application, Google Classroom, teacher room, etc. Then in collecting his assignments, the teacher can do it with video and audio demonstrations, then the evaluation media can be in the form of a project.

The learning application described above is a digitalbased learning method that can involve students directly, either as a source of learning or a source of student learning evaluation. so that digital citizenship competencies will go hand in hand with 21 st-century skills competencies which are also the goal of forming independent and intelligent citizens through Civics learning.

The statement above is a benchmark that the application of digital-based Civics learning will be closely related to efforts to strengthen the character of citizens who are ethical and behave by the personality of the Indonesian nation is using its digital media by the younger generation wisely.

Civics in this case can also play a role as the executor of 21 st-century learning. This is by the theory of the rainbow skills of the 21 st century (Trilling and Fadel, 2009). That learning should be able to improve students' 4C abilities such as communication, critical thinking, cooperation, etc. (Daryanto \& Karim, 2017)

This is consistent with research conducted (Dewi et al., 2021) concerning The Influence Of Project Citizen On Attitudes Nationalism In The Era. This research tries to study and analyze that the application of project 
citizen-based learning models is believed can produce and improve students' critical thinking skills.

So the difference with this study is that the object of study is that high school students as the younger generation meet the criteria for a society dependent on digital media or it can be said to be the characteristics of digital citizenship. To strengthen the ethics of digital citizenship of young citizens, it needs to be strengthened by using digital-based Civics learning with scientific and pedagogical models and methods as well as strategies that can increase the global knowledge of young citizens.

So that the relationship between Civics and digital citizenship is that the competence of digital citizens can be improved through Civics learning with a curricular system and learning objectives that lead to the formation of smart and ethical young citizens by Pancasila guidelines.

This is by the statement (Winataputra, U.S., \& Budimansyah, 2016) that to answer the challenges of 21 st-century learning, Civics is preparation for young citizens to answer the challenges of digital citizenship. Through Civics learning whose object is also to study the formation of the character of citizens.

\section{CONCLUSION}

Based on the results of the research and trying to answer the formulation of the problem in this research, it can be concluded that the teacher's strategy in implementing digital-based Civics learning in SMA to strengthen students' digital citizenship is that teachers integrate digital-based Civics learning competencies to strengthen digital citizenship in the syllabus and lesson plans that are adjusted to Civics learning curricular goal is to produce young citizens who are smart, independent and responsible.

In addition, teachers can apply problem-based learning models, which have pedagogical competencies, and learning innovations based on 21st-century learning to increase the knowledge and competence of digital citizens. Teachers must can understand and apply the concept of digital citizenship so that they can become examples of students in implementing digital-based Civics learning.

The teacher develops a digital-based learning model to engage students directly so that Civics learning becomes more meaningful and students can apply it in everyday life.

To continue to preserve the character of digital citizens who have ethics and rules in the use of digital media, a policy is needed as a tool to control and protect student rights in the context of accessing technology and information.

Teachers can build harmonious cooperation with parents, namely by ensuring the safety of children in using the internet and digital media and can clarify the function of electronic media and the purpose of their use.

The use of digital media by children must be based on an understanding of the concept of digital citizenship because it will affect the child's mindset and way of life.

Through this research, it can transform the value of digital citizenship in digital-based Civics learning, this research will construct the value of digital citizenship in digital-based Civics learning, then this research will strengthen the competence and concept of digital citizens in digital-based Civics learning.

\section{ACKNOWLEDGMENTS}

We give our deepest thanks and gratitude to God Almighty who has given all his gifts and guidance so that this article can be completed on time, also to the beloved of Allah who has given light in the dark life of the Prophet Muhammad. also to lecturers who always provide guidance and support to the author, as well as to both parents, thanks to his prayers and blessings this paper can be completed. Hopefully, the help and support from all parties can provide significant benefits for the generation and readers of this paper.

\section{REFERENCES}

(1) Baehaqi, D., \& Aulia, S. S. (2018). kewarga digital, Penguatan Wawasan Global Warga Negara, dan Peran PPKn. Seminar Nasional, Kongres Dan Deklarasi AP3KnI. http://eprints.uad.ac.id/id/eprint/6643

(2) Daryanto, \& Karim, S. (2017). Pembelajaran Abad 21 (Anggota IKAPI DIY (ed.); 1st ed.). Penerbit Gava Media.

(3) Dewi, D. A., Sunaria, N. H., Furnamasar, Y. F., \& Wahyuningsih, Y. (2021). The Influence Of Project Citizen On Attitudes Nationalism In The Era Digital Citizenship. American Journal of Multidisciplinary Research \& Development (AJMRD), 03(01), 08-12. https://www.ajmrd.com/wpcontent/uploads/2021/01/B310812.pdf

(4) Feriyansyah. (2015). Pembentukan Karakter Warga Negara Digital Sebagai Instrumen Untuk Meningkatkan Partisipasi Warga Negara Di Era Digital. Pusham Unimed, VI. https://doi.org/DOI: https://doi.org/10.24114/hpu.v6i1.10414

(5) Graeff, E. (2018). Evaluating civic technology design for citizen empowerment. Ph.D Thesis Submitted to the Program in Media Arts and Sciences in Partial Fulfillment of the Requirements for the Degree of Doctor of Philosophy in Media Arts and Sciences at the Massachusetts Institute of Technology.

(6) Howe, N., \& Strauss, W. (2017). Millennials Rising: The Next Great Generation. Vintage Books.

(7) Munir. (2017). Pembelajaran Digital (Ruswandi \& 
R. Firly (eds.)). PT. Alfabeta.

(8) Nazir, M. (2014). Metode Penelitian. Ghalia Indonesia.

(9) Prima Roza. (2020). Digital Citizenship: Menyiapkan Generasi Milenial Menjadi Warga Negara Demokratis Di Abad Digital. Psikologi Pendidikan, 19 No 2(Digital Citizenship), 190. https://doi.org/https://doi.org/10.5614/sostek.itbj.20 20.19.2.4

(10) Reichert, R., \& Karin, W.K., (eds). (2018). Mapping a changing field: a literature review on digital citizenship. Digital Culture \& Society. Digital Culture \& Society (DCS), 4(2).

(11) Sugiyono. (2006). Metode Penelitian Kuantitatif Kualitatif dan $R \& D$. Bandung: Alfabeta.

(12) Suryadi. (2009). Manajemen Mutu Berbasis Sekolah: Konsep dan Aplikasi. PT Sarana Panca Karya.

(13) Trilling and Fadel. (2009). 21st century skills: learning for life in our times. Jossey Bass.
(14) Wahab, abdul, \& Sapriya. (2011). Teori dan Landasan Pendidikan Kewarganegaraan (riduwan (ed.); 1st ed.). PT. Alfabeta Cv.

(15) Walangadi, H., Umar, E., \& Palilati, K. (2020). Membentuk siswa Sebagai Global Citizen melalui Mata Pelajaran PKn di Sekolah Dasar. Pengembangan Profesionalisme Guru Melalui Penulisan Karya Ilmiah Menuju Anak Merdeka Belajar, Prosiding. https://ejurnal.pps.ung.ac.id/index.php/PSI/article/vi ew/402/363

(16) Winataputra, U.S., \& Budimansyah, D. (eds). (2016). Pendidikan Kewarganegaraan dalam Perspektif Pendidikan Untuk Mencerdaskan Kehidupan Bangsa. Widya Aksara Press.

(17) Zook, C. (2019). What is digital citizenship \& how do you teach it? 